FEDERAL RESERVE BANK OF SAN FRANCISCO

WORKING PAPER SERIES

\title{
Small Business Lending Under the PPP and PPPLF Programs
}

\author{
Jose A. Lopez \\ Federal Reserve Bank of San Francisco \\ Mark M. Spiegel \\ Federal Reserve Bank of San Francisco \\ April 2021 \\ Working Paper 2021-10 \\ https://www.frbsf.org/economic-research/publications/working-papers/2021/10/
}

\section{Suggested citation:}

Lopez, Jose A., Mark M. Spiegel. 2021 "Small Business Lending Under the PPP and PPPLF Programs," Federal Reserve Bank of San Francisco Working Paper 2021-10. https://doi.org/10.24148/wp2021-10

The views in this paper are solely the responsibility of the authors and should not be interpreted as reflecting the views of the Federal Reserve Bank of San Francisco or the Board of Governors of the Federal Reserve System. 


\title{
SMALL BUSINESS LENDING UNDER THE PPP AND PPPLF PROGRAMS
}

\author{
JOSE A. LOPEZ \\ MARK M. SPIEGEL
}

\begin{abstract}
We examine the effects of the Paycheck Protection Program (PPP) and the PPP Liquidity Facility (PPPLF) on small business lending. The PPP was launched under the CARES Act of March 2020 to provide support for small businesses under the COVID-19 pandemic, while the PPPLF was an affiliated program administered by the Federal Reserve to facilitate the maintenance of liquidity among banks participating in the PPP. We use Call Report data to examine the contributions of these two programs on small business and farm lending by individual commercial banks in the United States. As participation in the programs was associated with lending to small businesses directly, we use an instrumental variables (IV) approach to identify a causal effect of the programs on lending based on historical bank relationships with the Small Business Administration that administered the PPP. Our results suggest that both the PPP and the PPPLF had a marked positive effect on growth in small business and farm lending over the first half of 2020 . However, while the PPP seemed to encourage greater lending growth by banks of all asset sizes, only small- and medium-sized bank lending was significantly influenced by participation in the PPPLF. We also find that while both programs had significant positive effects on small business lending, they did not influence small loans to farms over this period, which is likely due to a structural feature of the PPP. Finally, while participation in both programs increased bank balance sheets, we find that risk-adjusted bank capital ratios actually improved with PPP and PPPLF participation.
\end{abstract}

Date: April 8, 2021.

JEL classification: G14, G18, G32

Lopez: Federal Reserve Bank of San Francisco (Jose.A.Lopez@sf.frb.org); Spiegel: Federal Reserve Bank of San Francisco (Mark.Spiegel@sf.frb.org). Remy Beauregard provided excellent research assistance. We thank Judy Plock for helpful discussion about the data. The views expressed in this paper are those of the authors and do not necessarily reflect the views of the Federal Reserve Bank of San Francisco or the Federal Reserve System. 


\section{INTRODUCTION}

The start of the COVID-19 pandemic in the U.S. in the early weeks of 2020 and the accompanying quarantines and work-from-home orders severely affected the viability of many small businesses, especially those in the retail and service sectors. Small businesses play an integral role in the U.S. economy and particularly the labor market, accounting for nearly $47 \%$ of total employment and $41 \%$ of private-sector payrolls in the U.S. (S.B.A. (2019)). ${ }^{1}$ To address this challenge directly, the emergency fiscal package in the CARES Act created and funded the Paycheck Protection Program (PPP) to help firms retain their employees and cover other ongoing expenses. ${ }^{2}$ The PPP was administered through the SBA, which in turn relied on commercial banks and other financial institutions to underwrite forgivable loans to qualified firms. In addition, the Federal Reserve established the PPP Liquidity Facility (PPPLF) to provide loans to PPP lenders using the underlying PPP loans as collateral.

This paper focuses on the role that these two programs had in maintaining the flow of bank loans to small businesses during 2020. In particular, we examine the effect that a bank's participation in the PPP and the PPPLF had on its small business lending, as per regulatory Call Report filings in the second quarter of 2020.

Previous studies have established a positive correlation between both PPP and PPPLF participation and growth in small business lending (e.g. Beauregard et al. (2020)). However, the establishment of a causal link between participation in these two programs and small business lending raises the challenge of the endogeneity of banks' program participation decisions. Lenders faced a joint set of decisions under these COVID-related support programs; that is, the decision whether or not to extend a loan to a particular during this period, whether or not that loan would be submitted to through the PPP, and whether or not to use that loan as collateral under the Fed's PPPLF. The latter two decisions clearly affected the expected returns and risks that a bank would face on a given loan, and hence also had implications on the terms under which a bank would be willing to extend that loan. All of these considerations likely affected the volume of growth in small business and farm lending experienced by banks over this period.

\footnotetext{
${ }^{1}$ The definition of small business used for these summary statistics is an independent business with less than five hundred employees.

${ }^{2}$ The Coronavirus Aid, Relief, and Economic Security Act was a $\$ 2.2$ trillion fiscal package signed into law on March 27, 2020.
} 
To address the endogeneity of PPP and PPPLF participation, we use instrumental variables estimation, incorporating measures of the intensity of banks' interaction with the SBA prior to the crisis. It is quite likely that greater exposure to SBA lending prior to the crisis facilitated a bank's willingness to participate in the PPP. For example, as noted by Barraza et al. (2020), lenders that were already certified as SBA 7(a) banks prior to the launch of the PPP were automatically eligible for the program. ${ }^{3}$ Studies to date have shown that PPP lending was greater in areas that were more served by the SBA in 2019 (Liu and Volker (2020)) and bore little relation to economic conditions prevailing under COVID (Granja et al. (2020)). Our identification strategy requires that prior interactions with the SBA only affected growth in lending over this period through its influence on participation in the PPP and PPPLF. As both PPP and PPPLF participation are endogenous, our specification requires two instruments. We therefore examine two independent indicators of the potential intensity of bank alignment with the SBA based on pre-pandemic data. First, we consider the similarity in a bank's small business and farm lending mix by industry with that of the SBA in 2019. Our second instrument considers the intensity of a bank's lending through the SBA in 2019.

For the first half of 2020, our base regression specification shows that increased bank participation in these programs is a key explanatory variable for growth in small business lending, with both variables being positive and statistically significant. Notably, the coefficient on PPP participation is much larger than the one on PPPLF participation, which is reasonable as participation in the former is a requirement for participation in the latter. Our regression estimates suggest that a one standard deviation increase in our PPP participation metric is associated with a 32.5 percentage point increase in small business and farm lending growth relative to year-end 2019, while a one standard deviation increase in PPPLF participation appears to lead to a 6.6 percentage point increase in loan growth on average. Still, our results find a significant and economically meaningful impact of PPPLF participation even after controlling for participation in the PPP program.

Our bank-level specification allows us to condition on a variety of firm-specific characteristics, which highlight important differences in the determination of small business lending growth after accounting for participation in the PPP and PPPLF. Growth in small business lending across bank size categories varies in a statistically

\footnotetext{
${ }^{3}$ Lenders who were not previously certified were eligible subsequent to filing SBA Lender Agreement form 3506 (Barraza et al. (2020)).
} 
significant way, with smaller institutions engaging in much more lending of this type during 2020. This result matches Li and Strahan (2020), who argue that relationship lending was an important driver of the PPP's successful implementation. Our results support the notion that the differing business models used by banks of different asset sizes played a role in the implementation of this support policy and that smaller banks were able to increase their participation in light of these programs; see Bowman (2020). In fact, some of our robustness regressions suggest that PPPLF participation was a more important driver for small banks during this period. We also find that banks with stronger capital positions and more stable funding, such as having more core deposits, engaged in more small business lending during the first half of 2020, suggesting that banks in sounder condition were able to step up their lending during this challenging period and with the support of these governmental lending programs.

Finally, we consider the implications of the PPP and PPPLF for bank vulnerability, proxied for by changes in bank capital ratios. We examine both growth in total capital ratios and in risk-based capital ratios, since additional PPP lending could negatively affect a bank's total capital ratio but not its risk-adjusted capital ratio as these loans are guaranteed by the U.S. Treasury. While our results for total capital ratios suggest a potential deterioration with increased PPP and PPPLF participation, which would be expected as the growth in lending expands a bank's balance sheet, our results for growth in risk-adjusted capital ratios suggest no effect. Indeed, our point estimates indicate that a one standard deviation increase in PPPLF participation was associated over our sample period with an over 25 percentage point increase in growth in riskbased capital. As such, it appears that for banks that accessed the PPPLF, it was quite effective in mitigating deterioration in its risk-adjusted capital ratio associated with participation in PPP lending. This result shows the value added by the PPPLF in easing participation in and enhancing the effectiveness of the PPP.

The remainder of the paper is structured as follows. Section II provides a review of the literature on PPP lending, while Section III provides details on both the PPP and the PPPLF. Section IV details our empirical design, and Section V described our main regression results. Section VI presents a number of additional robustness results regarding our regression specification, sample, and other relevant dependent variables. 


\section{LITERATURE REVIEW}

Although the PPP was initiated in March 2020, its importance as a policy tool and its transparency with regard to sharing data on the loans underwritten has generated several research papers. As suggested by Hubbard and Strain (2020), the Paycheck Protection Program was the most creative fiscal policy response enacted in the U.S. to address the sharp economic decline brought about by the COVID pandemic.

The PPP is being administered by the Small Business Administration, and they have made the loan data available to researchers. The data contains several variables regarding the loan recipients - such as industry and geographic location - that allows study of the effect of the loans on local economies. Accordingly, most of the research has focussed on the effects of the PPP on the local economies into which the loans were granted. The dataset also contains information on the lending bank that administers each loan, which facilitates linking PPP lending activity with the banks' Reports of Condition and Income (i.e., the Call Reports) that provide balance sheet information. In addition, starting with the Call Reports in the second quarter of 2020, information on a bank's PPP activity - including items such as the number of loans outstanding, the outstanding balance of loans, and outstanding balance of PPP loans pledged to the PPPLF - are reported as well.

Based on data from the first wave of PPP lending as of April 2020, Granja et al. (2020) found no evidence that PPP funds flowed to more adversely affected areas as measured by declines in hours worked or business shutdowns. They also found interesting heterogeneity in the intensity of PPP participation across banks; for example, the four largest banks in the country distributed just 3\% of PPP loans in this first wave, even though they accounted for a much larger share of small business lending as of year-end 2019. Barraza et al. (2020) use data on the 2019 density of SBA member bank offices in a county as an instrument variable to account for inherent endogeneity and found that PPP lending did support local unemployment. Using an instrumental variable approach based on the size of the lending bank, Bartik et al. (2020) found a positive but imprecise effect on employment. Moreover, they found that PPP loans increased self-reported firm survival probability by a significant amount, suggesting that PPP loan recipients found these funds to be very valuable.

Li and Strahan (2020) use loan-level data to focus more directly on bank behavioral elements of the PPP. ${ }^{4}$ They find that overall lending grew more at banks with business

\footnotetext{
${ }^{4}$ Erel and Liebersohn (2020) examine the behavioral elements of non-bank lender participation in the PPP and find that they served as complements to bank lending by lending disproportionately
} 
models more typically associated with close borrower relationships (i.e., relationship lending). Their results suggest that this growth was due largely to the PPP program and that the causal connections between relationship measures and lending growth are present for PPP lending (not for other business loans. They found that lending grew faster at small banks, at banks with high levels of small business loans prior to the pandemic, and at banks funded using more retail deposits. Related work on relationship lending was conducted by Berger et al. (2021) and examined overall lending at the larger banks that file the supervisory Y14 dataset that contains loan-level data. They found that banks were generally more strict on their existing borrowers during the COVID-19 period. With respect to the PPP, they used PPP participation as an indicator of relationship lending, such that a high degree of participation may suggest less monitoring due the SBA guarantees. They found some evidence of banks with high PPP participation providing somewhat worse overall treatment of their relationship borrowers.

James et al. (2021) also focus on relationship lending and found that small banks responded faster and with more relative intensity to PPP loan applications than larger banks. Their results suggest that more PPP lending to small businesses took place in geographic areas in which community banks had higher market shares prior to the pandemic. Using pre-pandemic deposit shares as an instrument for the intensity of PPP lending, they found that this supported lending helped reduce local bankruptcies in a statistically significant way.

II.1. Program details. In response to the health and economic emergencies caused by the COVID-19 virus, the Coronavirus Aid, Relief, and Economic Security (CARES) Act was signed into law on March 27. We focus here on a key component of the legislation - the Paycheck Protection Program (PPP) - that was intended to be a revenuereplacement program to provide immediate relief to small businesses and help avoid business failures; see Hubbard and Strain (2020). The nearly $\$ 700$ billion program was to be implemented via the Treasury Department through the SBA. The PPP contained several components, such as a program that extended $\$ 17$ billion in payment relief to small businesses already holding SBA loans. However, our analysis concentrates on the nearly $\$ 350$ billion program for forgivable loans that would be used to pay up to eight weeks of payroll costs (including benefits) as well as certain immediate operating costs, such as rent and utilities. Businesses were permitted to

into zip code areas with fewer bank branches, lower incomes, to industries with less ex-ante small business lending, and into counties where the economic effects of the pandemic were more severe. 
borrow up to 2.5 times their average monthly payroll costs, capped at $\$ 10$ million. The loans carried minimal risk to borrowers since they could be forgiven if certain conditions were met, such as maintaining employee headcount or salary levels during the 24-week period (originally eight-week period) after the loan was originated.

The actual loans were underwritten by banks and carried a government guarantee. The PPP allowed banks to charge up to $5 \%$ of principal on loans up to $\$ 350,000,3 \%$ on loans between $\$ 350,000$ and $\$ 2$ million, and $1 \%$ on loans between $\$ 2$ and $\$ 10$ million. Although interest rates on these loans were low, banks received SBA fee payments, which increased their non-interest income. Importantly, PPP loans were assigned a zero weight for risk-weighted bank capital requirements. Finally, lenders were not held responsible for borrower misrepresentations, although anti-money-laundering compliance programs were still required. Thus, the PPP provided banks and potential borrowers with a relatively attractive package of loans and fees that were of mutual benefit.

The program was extended by the Paycheck Protection Program and Health Care Enhancement Act, which was enacted on April 24, 2020. The revised legislation increased PPP funding by $\$ 320$ billion to roughly $\$ 670$ billion. Further refinement of the program via the Paycheck Protection Program Flexibility Act (PPPFA) was signed into law on June 5, 2020. This Act extended the covered period for the forgivable loans from eight weeks to 24 weeks (or until December 31, 2020). The PPPFA also allowed businesses to spend 40 percent of forgivable funds on non-payroll expenses.

Further PPP extension was provided by the Economic Aid to Hard-Hit Small Businesses, Nonprofits and Venues Act (the "Economic Aid Act") passed in late December 2020 , which authorized a third round of PPP loans with an additional $\$ 284$ billion in funding. ${ }^{5}$ The legislation focused on providing new PPP loans to small businesses that had not received one and allowed certain existing borrowers to apply for a second loan. The legislation also targeted previously under-represented borrowers by limiting new loans to those underwritten by SBA-designated Community Financial Institutions and other small lenders. In addition, certain loan funds were designated for very small businesses (10 or fewer employees) and for loans below $\$ 250,000$ made in low- or moderate-income neighborhoods.

\footnotetext{
${ }^{5}$ https://www.frbsf.org/community-development/publications/community-development-researchbriefs/2021/march/ppp-lending-12th-district/
} 
With regards to agricultural production lending, ${ }^{6}$ the first set of PPP terms were based on existing SBA rules, which created eligibility and loan limits based on 2019 net farm profits. Due to widespread farm losses in 2019, this restriction limited PPP access to many self-employed farmers. In addition to providing additional funding for loan programs within the Department of Agriculture, the Economic Aid Act changed PPP application requirements for agricultural borrowers to the use of 2019 reported gross income.

The Federal Reserve was a major participant in the pandemic recovery effort through a variety of loan facilities that were funded through the Treasury Department. The facilities were used to purchase selected credit products from banks and thus provided them with additional liquidity and lending capacity. On April 8, the Federal Reserve Board of Governors authorized each of the twelve Federal Reserve Banks to establish and operate the PPP Liquidity Facility (PPPLF), which was designed to provide credit to eligible financial institutions that originate PPP loans by taking these loans as collateral at face value. ${ }^{7}$ Initially, the facility was limited to only depository institutions, but the eligibility requirements were extended to all SBA-qualified PPP lenders as of May. While depository institutions and credit unions must apply at their district Reserve Bank for PPPLF funding, specialized lenders need to apply to specific Reserve Banks; namely, community development financial institutions to the Federal Reserve Bank of Cleveland, members of farm credit community and small business lending companies to the Federal Reserve Bank of Minneapolis, and financial technology companies to the Federal Reserve Bank of San Francisco.

The terms of the PPPLF are relatively straightforward. No fees are charged, and credit is provided at an interest rate of 35 basis points. PPP loans are used as collateral and are priced at face value. In addition, SBA-approved institutions can post purchased PPP loans as collateral, although partial shares are not eligible. The PPPLF loan amount and maturity are set equal to the terms of the pledged PPP loan, and the maturity date is accelerated in cases of loan forgiveness, default, or retirement via SBA purchase. In addition to providing funding support to the PPP, the federal banking regulatory agencies further allowed banks to exclude any PPP loans used as PPPLF collateral from leverage-based regulatory capital and liquidity requirements; see Liu and Volker (2020).

\footnotetext{
${ }^{6}$ See BKD (2020) for further details, https://www.bkd.com/alert-article/2020/12/stimulus-aidfarmers-ranchers-second-chance-ppp-loans-eidl-grants.

${ }^{7}$ See Liu and Volker (2020) for further details.
} 
TABLE 1. PPP and PPPLF counts

\begin{tabular}{lcccc}
\hline \hline Program & Community & Medium & Large & Total \\
\hline Both & 464 & 129 & 28 & 621 \\
PPP only & 2880 & 461 & 85 & 3426 \\
Neither & 31 & 1 & 0 & 32 \\
\hline \hline
\end{tabular}

Source: Call Report data. 2020Q2 sample. Participation in PPP program based on greater than $1 \%$ value for PPPR variable, defined below.

Table 1 provides a summary of participation in the PPP and PPPLF by banks in our sample based on the three size categories that we examine in the following section. Of the 4,079 banks in our base sample, only 32 of them did not participate in the PPP, almost all of which were smaller community banks. However, $84 \%$ of banks participated in the PPP only, with about $84 \%$ of those banks being in the small bank category. This fact reflects the broad participation in the PPP across the size categories that we examine in our regression specification. Furthermore, over $15 \%$ of banks participated in both the PPP and PPPLF with again small banks making up just under $75 \%$ of that sub-sample.

\section{DATA AND METhodology}

III.1. Data and variable definitions. Our main dataset is the quarterly banklevel regulatory filings obtained from the Federal Financial Institutions Examination Council's "Call Reports", which provides detailed information on both balance sheet and income statement variables. All data is measured as quarter-end. We use 2019Q4 data to characterize bank conditions going into the pandemic and 2020Q2 data to examine small business and farm lending under the PPP and PPPLF programs. ${ }^{8}$

Our sample is a cross-section of U.S. commercial banks. Because we are interested in small business lending growth, banks must have some level of small business or farm lending in 2019Q4 to be included in the sample. ${ }^{9}$ We separate reporting banks into three groups based on asset size in 2019Q4; i.e., small banks with assets below $\$ 10$ billion, large banks with assets exceeding $\$ 100$ billion, and a middle category between them. Our base specification contains 4,083 banks, of which 3,371 are classified as

\footnotetext{
${ }^{8}$ Call Report data is compulsory for regulated banks, so this data source has no issues concerning potential endogeneity in reporting patterns. The Call Report was restructured as of 2020Q2 to collect information on Schedule RC-M regarding PPP loan extension and PPPLF participation.

${ }^{9}$ The relevant datafields are reported on Schedule RC-C, Part II of the Call Report. The same rules hold for our evaluation of small business or farm lending separately.
} 
small banks, 591 are medium-size banks, and 113 classified as large banks. We adopt the Call Report definition of small business and farm lending as business loans of $\$ 1$ million or less and farm loans of $\$ 500,000$ or less, respectively. ${ }^{10}$

We characterize PPP and PPPLF participation through the variables $P P P R$ and $P P P L F R$, respectively. $P P P R$ is measured as the ratio of $P P P$ participation, as reported in the Call Report, to total small business and farm lending. The PPP program included loans exceeding both our small business and farm lending level thresholds, going as high as $\$ 10$ million. As a result, it is possible, and happens in practice, that values of $P P P R$ can far exceed 1 . In response, we winsorize the data at a 5\% level, which reduced the high value of $P P P R$ to approximately $0.85 .{ }^{11}$ PPPLFR is defined as the ratio of bank borrowing from the PPPLF program relative to total lending through the PPP. Again, the differing loan size definitions in the data allow for the maximum value of PPPLFR to exceed one, and we respond by winsorizing at the $5 \%$ level.

Our dependent variables are primarily measures of growth in lending to small businesses and farms between 2019Q4 and 2020Q2 at the bank level. Our dependent variable in our base specification is $B \dot{U} S F$, which measures growth in small business and farm lending over that interval. Similarly $B \dot{U} S$ and $F A R M$ represent growth in small business and farm lending only, respectively, over that same interval.

We examine growth in bank lending over this period while conditioning for differences in individual bank characteristics going into the crisis. Conditioning for disparities in bank characteristics is potentially important, as, for example, Cornett et al. (2011) demonstrated that during the global financial crisis financial constraints inhibited credit expansion by banks. We follow the literature, such as Rice and Rose (2016) and Li and Strahan (2020), in the determination of Call Report conditioning variables to include in our specification, and use pre-pandemic 2019Q4 values. We include LIQASSET, which measures bank cash and security holdings as a share of total assets, as a measure of bank liquidity. We also include COREDEP, which measures core deposits relative to total assets as a measure of a banks' reliance on deposit funding. We also include $T C A P R$, a measure of the total capital ratio, to capture bank capital positions, and $L O A N C O M$ as a measure of outstanding loan

\footnotetext{
${ }^{10}$ In practice, it has been documented that these thresholds are potentially noisy indicators of lending to small businesses, as large businesses often take out loans of these small magnitudes. However, we follow the literature in adopting this as the definition of small business lending.

${ }^{11}$ The low value of $P P P R$ after winsorizing was around 0 . Prior to winsorizing, the values of $P P P R$ in our sample ranged from -0.99 to 800.68 .
} 
TABLE 2. Summary statistics

\begin{tabular}{lcccc}
\hline & mean & sd & $\max$ & $\min$ \\
\hline$B \dot{U} S F$ & 0.299 & 0.304 & 1.048 & -0.109 \\
$P P P R$ & 0.321 & 0.229 & 0.847 & 0.001 \\
$P P P L F R$ & 0.084 & 0.238 & 0.898 & 0.000 \\
$B \dot{U} S$ & 0.365 & 0.309 & 1.086 & -0.107 \\
$F A \dot{R} M$ & -0.007 & 0.145 & 0.361 & -0.301 \\
$T 1 R \dot{C} A P$ & -0.357 & 0.483 & 1.515 & -1.000 \\
$T C A P$ & -0.064 & 0.090 & 1.010 & -0.795 \\
\hline Observations & 4079 & & & \\
\hline
\end{tabular}

See text for definitions.

commitments, which have been shown to play a major role in encouraging lending during the COVID crisis (e.g. Greenwald et al. (2020)). As a number of banks experienced exceptionally large changes in their funding composition over this period, we also include a variable $C H G C O R E D E P$ to condition for changes in the share of core deposit funding between 2019Q4 and 2020Q2.

We are also interested in the implications of PPP and PPPLF participation for bank financial vulnerability. We therefore also examine movement in bank capital ratios from 2019Q4 to 2020Q2 in two ways. TCAP represents growth in the total capital ratio, while $T 1 R \dot{R} A P$ represents growth in tier 1 risk-based capital ratios.

Summary statistics for our variables of interest subsequent to winsorizing are shown in Table 2. Our data set exhibits a healthy degree of variability in our base specification dependent variable, small business and farm lending growth. On average, bank lending to small businesses grew rapidly during the pandemic, with total values ranging from approximately $-11 \%$ to positive 105\%. Growth in small business lending alone ranges from $-11 \%$ to positive $109 \%$ with a mean value of $37 \%$, while growth in bank small farm lending alone was close to 0 on average, and ranged from a low of $-30 \%$ to a high of $36 \%$.

III.2. Identification. Participation in the PPP program, and by association in the PPPLF program, will likely be endogenous to changes in bank lending activity during the COVID crisis. Lenders faced a joint set of decisions under the program. For banks, the decision included whether or not to extend a loan, whether or not that loan would be submitted to the PPP program, and whether or not to use the loan as collateral under the PPPLF facility. The latter two decisions clearly affected the 
expected returns and risks that banks would face on a given loan, and hence also had implications on the terms under which a bank would be willing to extend that loan. All of these considerations are likely to affect the volume of growth in small business and farm lending experienced by banks over this period.

To respond to the likely endogeneity of PPP and PPPLF participation, we turn to instrumental variables estimation. We consider measures of the intensity of bank interaction with the Small Business Administration (SBA) who administered PPP lending, prior to the crisis. It is quite likely that greater connections to the SBA going into the crisis facilitated bank participation in the PPP program. For example, Barraza et al. (2020) note that lenders that were already certified as SBA 7(a) banks prior to the launch of the PPP program were automatically eligible for the program. ${ }^{12}$ Studies to date have shown that PPP lending was greater in areas that were more served by the SBA in 2019 (Liu and Volker (2020)) and bore little relation to economic conditions prevailing under COVID (Granja et al. (2020)). Our identification strategy requires that prior interactions with the SBA only affected growth in lending over this period through its influence on participation in the PPP and PPPLF programs.

As both PPP and PPPLF participation are endogenous, our specification requires two instruments. We therefore examine two independent indicators of the intensity of bank alignment with the Small business Administration (SBA). First, we consider the similarity in a bank's small business and farm lending mix by industry with that of the SBA in 2019. This instrument, $I N D M I X_{i}$ is specified as the sum over all industries $j$ of the product of the share of SBA lending in industry $j$ and the share of bank small business and farm lending in industry $i$. INDMIX $X_{i}$ satisfies

$$
I N D M I X_{i}=\sum_{j}\left(\frac{S B A_{j}}{S B A} \cdot \frac{B U S F_{i, j}}{B U S F_{i}}\right),
$$

where $S B A_{j}$ represents SBA lending to industry $j$, SBA represents total SBA lending, $B U S F_{i, j}$ represents small business and farm lending by bank $i$ in industry $j$, and $B U S F_{i}$ represents total bank $i$ small business and farm lending. All values are measured for the duration of 2019. It is easy to verify that $I N D M I X_{i}$ is increasing in the similarity of the industry mixes of bank $i$ and the SBA.

For our second instrument, we consider the intensity of bank lending through the SBA in 2019. This instrument, $S B A 2019_{i}$ is specified as the ratio of SBA lending by bank $i$ to total bank $i$ small business and farm lending, which satisfies

\footnotetext{
${ }^{12}$ Lenders who were not previously certified were eligible subsequent to filing SBA Lender Agreement form 3506 (Barraza et al. (2020))
} 


$$
S B A 2019_{i}=\frac{S B A_{i}}{B U S F_{i}}
$$

where $S B A_{i}$ represents bank $i$ lending through the SBA and $B U S F_{i}$ represents total small business and farm lending by bank $i$, both in 2019 .

III.3. Estimation. Our base specification uses two-stage least squares estimation, with the two instruments $I N D M I X_{i}$ and $S B A 2019_{i}$ utilized for the endogenous variables PPPR and PPPLFR. The second stage of our specification satisfies

$$
B \dot{U S F} F_{i}=c+\beta_{1} P P P R_{i}+\beta_{2} P P P L F R_{i}+\beta X_{i}+S M A L L+M I D+\epsilon_{i}
$$

where $X_{i}$ denotes the set of conditioning variable discussed above, $\theta_{t}$ represents time fixed effects, $S M A L L$ and $M I D$ present 0-1 dummies representing small and medium banks, and $\epsilon_{i}$ represents the regression residual, with standard errors clustered by bank size. $^{13}$

\section{Results}

IV.1. Base specification. Our base specification results are shown in Table 3. Column 1 displays our base specification, with both endogenous variables under IV estimation. It can be seen that both of these variables of interest enter positively and significantly at more than a $1 \%$ confidence level. Our point estimates also indicate that these programs have had economically meaningful impacts on small business lending. Our point estimates and summary statistics in Table 1 imply that a one standard deviation increase in our PPP participation metric, $P P P R$, is associated with a 32.5 percentage point increase in small business and farm lending growth over this period, while a one standard deviation increase in PPPLFR is estimated to lead to a 6.6 percentage point increase in small business and farm lending growth on average. ${ }^{14}$

In terms of our conditioning variables, we obtain positive and significant results at a $1 \%$ confidence level for COREDEP, TCAPR, and CHGCOREDEP, indicating

\footnotetext{
${ }^{13}$ We allow three clusters, representing small, medium, and large banks, respectively.

${ }^{14}$ We evaluate the strength of our instruments in Appendix Table A1. As both PPPR and $P P P L F R$ range from 0 to 1 , we report both TOBIT estimation results for the first stage as well as the actual first stage results. Both instruments enter with their predicted signs for both the PPPR and PPPLFR under both specifications. We also ran the AR Wald weak instrument test and obtained an $\mathrm{F}$ value of 692.58 , which rejects weak instruments at a $1 \%$ level, and a Stock-Yogo statistic of 7.39 , which passes the 7.03 critical value for a $10 \%$ confidence level. Weak instrument tests for individual endogenous variable specifications yielded similar results.
} 
TABLE 3. Base specification

\begin{tabular}{|c|c|c|c|c|c|c|}
\hline & (1) & $(2)$ & $(3)$ & $(4)$ & (5) & (6) \\
\hline VARIABLES & IV & IV & IV & OLS & OLS & OLS \\
\hline PPPR & $\begin{array}{c}1.425^{* * *} \\
(0.084)\end{array}$ & $\begin{array}{c}1.298^{* * *} \\
(0.080)\end{array}$ & & $\begin{array}{c}0.867 * * * \\
(0.010)\end{array}$ & $\begin{array}{c}0.850^{* * *} \\
(0.005)\end{array}$ & \\
\hline PPPLFR & $\begin{array}{c}0.278^{* * *} \\
(0.097)\end{array}$ & & $\begin{array}{c}1.345^{* * *} \\
(0.249)\end{array}$ & $\begin{array}{c}0.055^{* *} \\
(0.007)\end{array}$ & & $\begin{array}{l}0.176^{*} \\
(0.046)\end{array}$ \\
\hline LIQASSET & $\begin{array}{c}0.015 \\
(0.073)\end{array}$ & $\begin{array}{c}0.093^{* * *} \\
(0.026)\end{array}$ & $\begin{array}{c}0.546^{* * *} \\
(0.124)\end{array}$ & $\begin{array}{c}0.136 \\
(0.071)\end{array}$ & $\begin{array}{c}0.099 \\
(0.042)\end{array}$ & $\begin{array}{l}0.382^{*} \\
(0.091)\end{array}$ \\
\hline COREDEP & $\begin{array}{c}0.341^{* * *} \\
(0.128)\end{array}$ & $\begin{array}{c}0.019 \\
(0.030)\end{array}$ & $\begin{array}{c}0.574^{* * *} \\
(0.122)\end{array}$ & $\begin{array}{l}-0.046 \\
(0.049)\end{array}$ & $\begin{array}{c}-0.073^{* *} \\
(0.013)\end{array}$ & $\begin{array}{c}-0.301^{* * *} \\
(0.030)\end{array}$ \\
\hline TCAP & $\begin{array}{c}0.834^{* * *} \\
(0.129)\end{array}$ & $\begin{array}{c}0.462^{* * *} \\
(0.062)\end{array}$ & $\begin{array}{c}0.726^{* * *} \\
(0.251)\end{array}$ & $\begin{array}{c}0.233^{* *} \\
(0.038)\end{array}$ & $\begin{array}{c}0.048^{* *} \\
(0.008)\end{array}$ & $\begin{array}{c}-0.314^{* *} \\
(0.054)\end{array}$ \\
\hline LOANCOM & $\begin{array}{c}-1.602^{* * *} \\
(0.305)\end{array}$ & $\begin{array}{c}-0.079^{* *} \\
(0.036)\end{array}$ & $\begin{array}{c}0.974^{* * *} \\
(0.132)\end{array}$ & $\begin{array}{l}-0.383 \\
(0.213)\end{array}$ & $\begin{array}{l}-0.031 \\
(0.013)\end{array}$ & $\begin{array}{c}1.367^{* *} \\
(0.252)\end{array}$ \\
\hline CHGCOREDEP & $\begin{array}{c}1.098^{* * *} \\
(0.414)\end{array}$ & $\begin{array}{c}0.169 \\
(0.108)\end{array}$ & $\begin{array}{c}2.492^{* * *} \\
(0.524)\end{array}$ & $\begin{array}{c}-0.291^{* *} \\
(0.045)\end{array}$ & $\begin{array}{c}-0.418^{* *} \\
(0.048)\end{array}$ & $\begin{array}{c}-1.028^{* * *} \\
(0.022)\end{array}$ \\
\hline SMALLBANK & $\begin{array}{c}0.158^{* * *} \\
(0.030)\end{array}$ & $\begin{array}{c}0.175^{* * *} \\
(0.028)\end{array}$ & $\begin{array}{c}-0.113^{* * *} \\
(0.019)\end{array}$ & $\begin{array}{c}0.011 \\
(0.010)\end{array}$ & $\begin{array}{c}0.027^{* * *} \\
(0.002)\end{array}$ & $\begin{array}{c}-0.188^{* * *} \\
(0.014)\end{array}$ \\
\hline MIDBANK & $\begin{array}{c}0.081^{* * *} \\
(0.013)\end{array}$ & $\begin{array}{c}0.086^{* * *} \\
(0.008)\end{array}$ & $\begin{array}{c}0.021^{* *} \\
(0.010)\end{array}$ & $\begin{array}{c}0.036^{* *} \\
(0.007)\end{array}$ & $\begin{array}{c}0.045^{* * *} \\
(0.001)\end{array}$ & $\begin{array}{l}-0.018 \\
(0.008)\end{array}$ \\
\hline Constant & $\begin{array}{c}-0.651^{* * *} \\
(0.169)\end{array}$ & $\begin{array}{c}-0.333^{* * *} \\
(0.044)\end{array}$ & $\begin{array}{c}-0.365^{* *} \\
(0.171)\end{array}$ & $\begin{array}{c}0.013 \\
(0.027)\end{array}$ & $\begin{array}{c}0.044^{* *} \\
(0.009)\end{array}$ & $\begin{array}{c}0.645^{* * *} \\
(0.031)\end{array}$ \\
\hline Observations & 4,079 & 4,741 & 4,086 & 4,079 & 4,741 & 4,086 \\
\hline R-squared & 0.291 & 0.372 & & 0.445 & 0.469 & 0.165 \\
\hline
\end{tabular}

that deposit-intensive and well-capitalized banks had higher small business lending growth, as did banks with high growth in their shares of core deposit funding. In contrast, we obtain a significantly negative coefficient estimate for $L O A N C O M$, our measure of outstanding loan commitments, implying that banks with greater commitments experienced less growth in small business lending. This is intuitive, as holding all else equal, we would expect that banks that holding all else equal, lending growth would be higher among banks with more stable funding, higher capital ratios, and lower outstanding loan commitments. LIQASSET is insignificant. 
Lastly, our dummies for small and medium-sized banks both enter positively, while our constant term enters negatively. This implies lower small business lending growth among large banks over this period. Moreover, our standard deviation estimates are also sufficiently small to infer that small business lending growth was higher for small banks than medium-sized banks.

As we believe that both programs play a substantive role in influencing small business lending decisions, our column 1 specification is taken as our base. However, in order to ensure that the combination of the two endogenous variables was not driven by any spurious results, columns 2 and 3 repeat our specification with PPPLFR and PPPR dropped respectively. Column 2 shows that dropping PPPLFR does not markedly change our estimate for the coefficient on PPPR, which continues to enter positively and significantly, with a modestly lower point estimate. Similarly, column 3 demonstrates that the positive and significant estimate we obtain from PPPLFR is robust to dropping PPPR rom our specification, although in this case the coefficient estimate is notably larger. As both models are under-specified in our opinion, however, we do not place as much confidence in these different point estimates relative to our base specification.

To demonstrate that our results are not driven by our IV estimation and choice of instruments, columns 4 through 6 repeat our specification using ordinary least squares estimation, again with standard errors clustered by size. Column 4 repeats our base specification. Coefficient values on our variables of interest are smaller than under our IV specification, but continue to enter significantly positive. Our conditioning variables do demonstrate some differences. Columns 5 and 6 drop our endogenous variables one at a time and estimate under ordinary least squares. As in our IV specifications, both variables continue to enter positively and with statistical significance, albeit with smaller point estimates.

IV.2. Samples split by size. As large banks enjoyed a potential advantage in increasing lending under the PPP program because they largely had electronic platforms in place allowing them to capitalize on the first-come=first-served format of the PPP program, we investigate the robustness of our results by splitting the sample into two sub-samples, one containing our small and medium-sized banks, and the other containing the large banks in our sample, again under our IV estimation. As in our base specification table, we report three specifications for each sample, one with both endogenous variables included, and then one each with one of the variables dropped. 
Our results are reported in Table 4 . Columns 1 through 3 report our results for our sample of small and medium banks. These constitute the bulk of our full sample, with our base specification sample having 3,966 observations. This specification is reported in column 1. Our variables of interest continue to enter positively and significantly, with very similar coefficient magnitudes to those we obtained in our full sample. The conditioning variables also enter with qualitatively similar signs and significance. Columns 2 and 3 again drop the endogenous variables one at a time. As in our full sample, both variables also continue to enter positively and significantly on their own.

TABLE 4. Split sample

\begin{tabular}{|c|c|c|c|c|c|c|}
\hline & $\begin{array}{c}\text { (1) } \\
\text { SM/MID banks }\end{array}$ & $\begin{array}{c}\text { (2) } \\
\text { SM/MID banks }\end{array}$ & $\begin{array}{c}(3) \\
\text { SM/MID banks }\end{array}$ & $\begin{array}{c}(4) \\
\text { LG banks }\end{array}$ & $\begin{array}{c}(5) \\
\text { LG banks }\end{array}$ & $\begin{array}{c}(6) \\
\text { LG banks }\end{array}$ \\
\hline PPPR & $\begin{array}{c}1.429^{* * *} \\
(0.091)\end{array}$ & $\begin{array}{c}1.306^{* * *} \\
(0.087)\end{array}$ & & $\begin{array}{l}1.034^{*} \\
(0.561)\end{array}$ & $\begin{array}{c}1.180^{* * *} \\
(0.401)\end{array}$ & \\
\hline PPPLFR & $\begin{array}{c}0.215^{* * *} \\
(0.013)\end{array}$ & & $\begin{array}{c}1.355^{* * *} \\
(0.205)\end{array}$ & $\begin{array}{c}0.586 \\
(1.248)\end{array}$ & & $\begin{array}{c}1.564 \\
(1.695)\end{array}$ \\
\hline LIQASSET & $\begin{array}{l}-0.009 \\
(0.084)\end{array}$ & $\begin{array}{c}0.083^{* * *} \\
(0.031)\end{array}$ & $\begin{array}{c}0.568^{* * *} \\
(0.105)\end{array}$ & $\begin{array}{c}0.419 \\
(0.908)\end{array}$ & $\begin{array}{c}0.533 \\
(0.868)\end{array}$ & $\begin{array}{l}-0.453 \\
(1.162)\end{array}$ \\
\hline COREDEP & $\begin{array}{c}0.316^{* * *} \\
(0.109)\end{array}$ & $\begin{array}{c}0.040^{* * *} \\
(0.008)\end{array}$ & $\begin{array}{c}0.476^{* * *} \\
(0.108)\end{array}$ & $\begin{array}{c}0.650 \\
(2.898)\end{array}$ & $\begin{array}{l}-0.337 \\
(0.473)\end{array}$ & $\begin{array}{c}3.147 \\
(3.844)\end{array}$ \\
\hline TCAP & $\begin{array}{c}0.795^{* * *} \\
(0.102)\end{array}$ & $\begin{array}{c}0.499^{* * *} \\
(0.070)\end{array}$ & $\begin{array}{c}0.610^{* *} \\
(0.250)\end{array}$ & $\begin{array}{c}1.765 \\
(2.697)\end{array}$ & $\begin{array}{l}-0.026 \\
(0.938)\end{array}$ & $\begin{array}{c}3.014 \\
(3.916)\end{array}$ \\
\hline LOANCOM & $\begin{array}{c}-1.790^{* * *} \\
(0.316)\end{array}$ & $\begin{array}{c}-0.080^{* *} \\
(0.037)\end{array}$ & $\begin{array}{c}0.899^{* * *} \\
(0.113)\end{array}$ & $\begin{array}{c}0.748 \\
(0.818)\end{array}$ & $\begin{array}{c}0.021 \\
(0.612)\end{array}$ & $\begin{array}{l}1.736^{*} \\
(0.926)\end{array}$ \\
\hline CHGCOREDEP & $\begin{array}{c}0.898^{* * *} \\
(0.193)\end{array}$ & $\begin{array}{c}0.178 \\
(0.117)\end{array}$ & $\begin{array}{c}2.533^{* * *} \\
(0.359)\end{array}$ & $\begin{array}{c}1.262 \\
(3.133)\end{array}$ & $\begin{array}{l}-0.007 \\
(1.009)\end{array}$ & $\begin{array}{c}2.538 \\
(4.584)\end{array}$ \\
\hline SMALLBANK & $\begin{array}{c}0.070^{* * *} \\
(0.014)\end{array}$ & $\begin{array}{c}0.091^{* * *} \\
(0.022)\end{array}$ & $\begin{array}{c}-0.134^{* * *} \\
(0.007)\end{array}$ & & & \\
\hline Constant & $\begin{array}{c}-0.526^{* * *} \\
(0.126)\end{array}$ & $\begin{array}{c}-0.272^{* * *} \\
(0.040)\end{array}$ & $\begin{array}{l}-0.248 \\
(0.155)\end{array}$ & $\begin{array}{l}-1.047 \\
(2.697)\end{array}$ & $\begin{array}{c}0.043 \\
(0.439)\end{array}$ & $\begin{array}{l}-2.713 \\
(3.813)\end{array}$ \\
\hline Observations & $\begin{array}{l}3,966 \\
0305\end{array}$ & 4,613 & 3,973 & 113 & 128 & 113 \\
\hline
\end{tabular}

Note: Dependent variable: Growth in small business and farm lending from 2019Q4 through 2020Q2. Instrumental variables estimation. See text for variable definitions. Standard errors in parentheses clustered by bank size. SM/MD and LG identify samples with small and mid-sized or large banks respectively. ${ }^{* * *} \mathrm{p}<0.01 ;{ }^{* *} \mathrm{p}<0.05 ;{ }^{*} \mathrm{p}<0.1$ 
Columns 4 through 6 repeat our base specifications for our large bank sub-sample. Column 4 reports our base specification, with both endogenous variables included. Our large bank sample contains 113 observations. These variables both enter positively, with comparable point estimates. However, PPPR now only enters at a $10 \%$ confidence level, and PPPLFR is insignificant. When entered on its own (Column 5), PPPR enters with statistical significance at a $1 \%$ level. However, column 6 shows that PPPLFR continues to enter insignificantly different from 0 for large banks when included on its own.

Taken together, our results with the samples split by bank size reveal that the programs had different implications for large and small banks. The PPP program has a positive and statistically significant impact on all banks in our sample. However, PPPLF program participation proved much more important for small business and farm lending growth among small and medium-sized bank lending growth than it was for large banks. This result is consistent with the perception that small banks in particular relied on the PPPLF program to participate in the PPP program without placing undesirable pressure on their overall liquidity positions.

IV.3. Small businesses and farm lending growth separately. Table 5 repeats our base specification with our dependent variable changed to separate measures of small business lending growth and small farm lending growth. Results for small business lending growth only are shown in columns 1 through 3 . Column 1 reports the results for our base specification with both endogenous variables included. Both of our variables of interest, $P P P R$ and $P P P L F R$ enter positively and significantly, with coefficient values similar to those for small business and farm lending growth. We also obtain results that are similar to those we obtained in our base specification with each of the variables of interest entered separately, as shown in columns 2 and 3. Both PPPR and PPPLFR enter positively and significantly for small business lending only, as they did for small business and farm lending growth together.

However, our results for small farm lending growth alone, reported in columns 4 through 6 , are quite different. Column 4, which reports our results with both of variables of interest included shows both entering quite insignificantly, with both $P P P R$ and PPPLFR actually entering with a negative point estimate. Columns 5 and 6 demonstrate that introducing our endogenous variables one at a time does not rescue their significance, as $P P P R$ and PPPLFR both continue to enter insignificantly different from zero with negative point estimates. Our results therefore suggest that while participation in the PPP and PPPLF programs were related to enhanced small 
TABLE 5. Small business and farm lending only

\begin{tabular}{|c|c|c|c|c|c|c|}
\hline & $\begin{array}{c}(1) \\
\text { Sm businesses }\end{array}$ & $\begin{array}{c}(2) \\
\text { Sm businesses }\end{array}$ & $\begin{array}{c}(3) \\
\text { Sm businesses }\end{array}$ & $\begin{array}{c}(4) \\
\text { Farms }\end{array}$ & $\begin{array}{c}(5) \\
\text { Farms }\end{array}$ & $\begin{array}{c}(6) \\
\text { Farms }\end{array}$ \\
\hline PPPR & $\begin{array}{c}1.175^{* * *} \\
(0.064)\end{array}$ & $\begin{array}{c}1.196^{* * *} \\
(0.078)\end{array}$ & & $\begin{array}{l}-0.053 \\
(0.063)\end{array}$ & $\begin{array}{l}-0.093 \\
(0.107)\end{array}$ & \\
\hline PPPLFR & $\begin{array}{c}0.304^{* * *} \\
(0.050)\end{array}$ & & $\begin{array}{c}0.976^{* * *} \\
(0.198)\end{array}$ & $\begin{array}{l}-0.285 \\
(0.337)\end{array}$ & & $\begin{array}{l}-0.314 \\
(0.318)\end{array}$ \\
\hline LIQASSET & $\begin{array}{l}-0.017 \\
(0.059)\end{array}$ & $\begin{array}{l}-0.009 \\
(0.023)\end{array}$ & $\begin{array}{c}0.427^{* * * *} \\
(0.106)\end{array}$ & $\begin{array}{c}0.008 \\
(0.091)\end{array}$ & $\begin{array}{c}0.034 \\
(0.025)\end{array}$ & $\begin{array}{l}-0.013 \\
(0.080)\end{array}$ \\
\hline COREDEP & $\begin{array}{l}0.269^{*} \\
(0.142)\end{array}$ & $\begin{array}{c}0.007 \\
(0.046)\end{array}$ & $\begin{array}{c}0.299 * * * \\
(0.042)\end{array}$ & $\begin{array}{l}-0.165 \\
(0.254)\end{array}$ & $\begin{array}{c}0.056^{* *} \\
(0.024)\end{array}$ & $\begin{array}{l}-0.172 \\
(0.251)\end{array}$ \\
\hline TCAP & $\begin{array}{c}0.671^{* * *} \\
(0.095)\end{array}$ & $\begin{array}{c}0.247^{* * *} \\
(0.075)\end{array}$ & $\begin{array}{c}0.422^{* *} \\
(0.170)\end{array}$ & $\begin{array}{l}-0.265 \\
(0.250)\end{array}$ & $\begin{array}{l}-0.109 \\
(0.078)\end{array}$ & $\begin{array}{l}-0.263 \\
(0.244)\end{array}$ \\
\hline LOANCOM & $\begin{array}{c}-1.236^{* * *} \\
(0.254)\end{array}$ & $\begin{array}{c}-0.076^{* *} \\
(0.032)\end{array}$ & $\begin{array}{c}0.942^{* * *} \\
(0.126)\end{array}$ & $\begin{array}{c}0.188 \\
(0.165)\end{array}$ & $\begin{array}{l}-0.022^{*} \\
(0.011)\end{array}$ & $\begin{array}{c}0.095 \\
(0.111)\end{array}$ \\
\hline CHGCOREDEP & $\begin{array}{c}0.824^{* * *} \\
(0.274)\end{array}$ & $\begin{array}{c}0.012 \\
(0.100)\end{array}$ & $\begin{array}{c}1.352^{* * *} \\
(0.453)\end{array}$ & $\begin{array}{l}-0.959 \\
(1.024)\end{array}$ & $\begin{array}{l}-0.140 \\
(0.115)\end{array}$ & $\begin{array}{l}-0.972 \\
(0.999)\end{array}$ \\
\hline SMALLBANK & $\begin{array}{c}0.144^{* * *} \\
(0.021)\end{array}$ & $\begin{array}{c}0.187^{* * *} \\
(0.023)\end{array}$ & $\begin{array}{c}-0.092^{* * *} \\
(0.018)\end{array}$ & $\begin{array}{c}-0.050^{* *} \\
(0.021)\end{array}$ & $\begin{array}{l}-0.055 \\
(0.044)\end{array}$ & $\begin{array}{l}-0.038 \\
(0.023)\end{array}$ \\
\hline MIDBANK & $\begin{array}{c}0.082^{* * *} \\
(0.009)\end{array}$ & $\begin{array}{c}0.097^{* * *} \\
(0.005)\end{array}$ & $\begin{array}{c}0.025^{* *} \\
(0.011)\end{array}$ & $\begin{array}{c}-0.029 * * * \\
(0.011)\end{array}$ & $\begin{array}{l}-0.027^{*} \\
(0.017)\end{array}$ & $\begin{array}{c}-0.025^{* *} \\
(0.012)\end{array}$ \\
\hline Constant & $\begin{array}{c}-0.431^{* * *} \\
(0.159)\end{array}$ & $\begin{array}{c}-0.216^{* *} \\
(0.085)\end{array}$ & $\begin{array}{l}-0.015 \\
(0.088)\end{array}$ & $\begin{array}{c}0.235 \\
(0.281)\end{array}$ & $\begin{array}{c}0.029 \\
(0.092)\end{array}$ & $\begin{array}{c}0.220 \\
(0.281)\end{array}$ \\
\hline Observations & 3,971 & 4,585 & 3,975 & 3,421 & 3,871 & 3,425 \\
\hline R-squared & 0.266 & 0.351 & & & & \\
\hline
\end{tabular}

Note: Dependent variable: Growth in small business or farm lending from 2019Q4 through 2020Q2, as indicated. Instrumental variables estimation. See text for variable definitions. Standard errors in parentheses clustered by bank size. ${ }^{* * *} \mathrm{p}<0.01 ;{ }^{* *} \mathrm{p}<0.05{ }^{*} \mathrm{p}<0.1$

business growth during the COVID crisis, it was not associated with growth in small loans to farms.

\section{Robustness CHECKS}

V.1. Changes in specification. We next pursue some further checks of the robustness of our base specification results. We first consider perturbations to our base specification. Our results are summarized in Table 6. We consider lagged bank lending growth and levels, to account for potential trends in business and farm lending 
that may spuriously interact with individual banks' intensity of PPP and PPPLF participation. Columns 1 through 3 introduce these terms. Column 1 adds lagged small business and farm lending growth, measured as growth in small business and farm lending from 2019Q2 to 2019Q4. Column 2 adds lagged levels of small business and farm lending, measured as total lending for 2019. Finally column 3 adds both.

It can be seen that our base specification is robust to all of these inclusions, as PPPR and PPPLFR continue to enter positively and significantly. Indeed, our point estimates for our variables of interest are modestly higher than those in our base specification.

We also consider an alternative measure of the intensity of bank interaction with the SBA in 2019. We introduce a third instrument, which measures the ratio of bank 7(a) SBA lending in 2019 to bank small business and farm lending in that year. We then proceed to estimate our base specification using these three instruments. Our results are shown in column 4. Both PPPR and PPPLFR enter positively and significantly, with similar magnitude coefficient estimates to those in our base specification.

Finally, we consider using the risk-based tier 1 capital ratio, TIER $1 C A P$, as our conditioning variable instead of the total capital ratio. We substitute this alternative measure of bank capital adequacy in column 5. Again, our coefficient estimates for variables of interest, $P P P R$ and PPPLFR, are robust to the inclusion of this alternative capital adequacy measure. Both variables continue to enter positively and significantly, with similar point estimates.

V.2. Changes in estimation. We next consider a variety of perturbations to our estimation methodology. Our results are shown in Table 7. Column 1 reports the results of our estimation using heteroscedasticity-robust standard errors, rather than clustering by bank size in our standard error estimation. This alternative standard error estimation for our full sample does yield a difference in our results. While PPPR continues to enter positively and significantly, PPPLFR is now insignificantly different from zero, although it continues to enter with a similar magnitude positive coefficient estimate. Column 2 reports results for our base specification under regular standard errors. These yield similar results to those that we obtained for the robust standard error estimation. $P P P R$ continues to enter positively and significantly with similar point estimates, but PPPLFR enters insignificantly different from 0 . Given our disparate results for our large bank sub-sample above, it is possible that the lack of influence of the PPPLF participation on large bank lending is driving this result. 
Column 3 weights our observations by the intensity of bank participation in small business and farm lending relative total assets. Our results for PPPR are again robust to this alternative specification, while PPPLFR again is insignificant.

Column 4 also winsorizes our conditioning variables at a $5 \%$ level. In this case, both PPPR and PPPLFR continue to enter positively and significantly with coefficient estimates of similar magnitudes. ${ }^{15}$

Overall, our qualitative results that participation in the programs supported small business and farm lending are robust to our perturbations to our estimation methods for the PPPR variable. However, our weaker results for PPPLFR suggest that this program was more important for small banks than for large ones in encouraging lending growth.

\section{V.3. Program impacts on bank capital ratios. As the PPP and PPPLF pro-} grams appear to have encouraged additional lending during the COVID crisis, it is possible that they encouraged banks to move to more vulnerable financial positions. To investigate this possibility, we also examine movement in bank capital ratios over our sample period. We consider both growth in the total capital ratio, TCAP, and growth in tier 1 risk-based capital ratios, $T 1 R \dot{R} A P$. The distinction is important, as additional lending under the PPP program would negatively impact on a bank's measured total capital ratio, but since the loans were guaranteed by the Treasury, they should not harm a bank's risk-adjusted capital ratio. Indeed, if a bank substituted lending under the guaranteed PPP program (which receives a zero risk weight) for a loan which carries some level of risk, tier-1 capital ratios should increase with PPP participation.

Our results are shown in Table 8. We first examine developments in banks' riskadjusted tier 1 based capital ratios. Column 1 reports the results for growth in tier 1 based risk adjusted capital ratios based on the same right hand side variables and instruments used in our base bank lending growth specification. Both our coefficient estimates for PPPR and PPPLFR are positive and significant. Our coefficient point estimates suggest that a one standard deviation increase in participation in the PPP and PPPLF programs are associated with 13.3 and 30.7 percentage point increases in growth in a bank's tier 1 risk-adjusted capital ratio respectively. As such, it appears that both the PPP and PPPLF programs were effective in mitigating any deterioration

\footnotetext{
${ }^{15}$ We also consider alternative outlier treatments, including alternative winsorizing strategies and truncation, in Appendix Table A2. Our results for the PPPR coefficient estimate are generally robust to these perturbations, but the results for the $P P P L F$ variable exhibit sensitivity.
} 
in risk-adjusted capital ratios. Columns 2 and 3 run the same specification with only one of these variables of interest included. We obtain a positive and significant coefficient on both of the variables, with similar coefficient magnitudes to those we observed in our base specification.

In contrast, columns 4 through 6 report the impact of PPP and PPPLF participation on total capital ratios. These specifications universally yield a statistically significant negative coefficient estimate on both PPPR and PPPLFR, indicating that participation in the PPP program, which was associated with increased lending as we saw above, expanded bank balance sheets and may be erroneously associated with increased bank vulnerability. However, as our risk-adjusted capital ratio results demonstrate, such an inference would be incorrect, as the risk associated with the increase in bank balance sheets under these programs were borne largely by the US Treasury, not by the banks themselves, and hence did not result in increased bank vulnerability.

\section{COnClusion}

Small businesses play an integral role in the U.S. economy and particularly the labor market. Accordingly, the arrival of the COVID-19 pandemic in the U.S. in the early weeks of 2020 and the accompanying work-from-home orders severely affected this sector of the economy and raised the possibility of a major wave of small business failures. To address this challenge, the emergency fiscal package in the CARES Act created and funded the PPP to help these firms retain their employees and cover ongoing expenses. The PPP was structured to be administered through the SBA, which in turn relied on banks and other financial institutions to underwrite forgivable loans to qualified firms. The loans were guaranteed by the SBA, which paid fees to the underwriting banks. In addition, the Federal Reserve established the PPP Liquidity Facility (PPPLF) to provide even more funding to PPP lenders by providing loans using the underlying PPP loans as collateral.

Several studies have examined the effect of the PPP on regional economic conditions, such as the change in local employment in geographic areas receiving PPP loans. In this paper, we focus more directly on the role that these two programs had in maintaining the flow of bank loans to small businesses during 2020. In particular, we examine the effect that a bank's participation in the PPP and the PPPLF has on its small business lending, as per regulatory Call Report filings in the second and fourth quarters of 2020. To respond to the likely endogeneity of PPP and PPPLF 
participation, we use an instrumental variables approach based on measures of the intensity of bank interaction with the SBA in 2019 prior to the crisis.

Our base regression specification shows that increased bank participation in these programs is a key explanatory variable for growth in small business lending, with both variables being positive and statistically significant. Notably, the coefficient on PPP participation is much larger than the one on PPPLF participation, which is reasonable as participation in the former is a requirement for participation in the latter. Our regression estimates suggest that a one standard deviation increase in our PPP participation metric is associated with a nearly 30 percentage point increase in small business and farm lending growth relative to year-end 2019, while a one standard deviation increase in PPPLF participation appears to lead to a 9.1 percentage point increase in loan growth on average.

Further analysis shows that growth in small business lending varies in a statistically significant way across across bank size categories, with smaller institutions engaging in much more lending of this type during 2020. Our results support the notion that the differing business models used by banks of different sizes played a role in the implementation of this support policy, and that smaller banks were able to increase their participation in light of these programs; see Bowman (2020). In fact, some of our robustness regressions suggest that PPPLF participation was a more important driver for small banks during this period. We also find that banks with stronger capital positions and more stable funding, such as more core deposits, engaged in more small business lending during this period, suggesting that banks in sounder condition were able to step up their lending during this challenging period and with the support of these governmental lending programs.

Finally, we consider the implications of the PPP and PPPLF for bank vulnerability, proxied by changes in bank capital ratios. While our results for total capital ratios suggest a potential deterioration with increased PPP and PPPLF participation, our results for growth in risk-adjusted capital ratios demonstrates that after accounting for the fact that PPP loans were guaranteed, that was not the case. Indeed, our point estimates indicate that a one standard deviation increase in PPP and PPPLF participation was associated over our sample period with substantial 13.3 and 25.8 percentage point increases in growth in tier 1 risk-adjusted capital ratios. As such, it appears that these programs were quite effective in mitigating any deterioration in risk-adjusted capital ratio associated with participation in PPP lending. 
TABLE 6. Changes in specification

\begin{tabular}{|c|c|c|c|c|c|}
\hline & $\begin{array}{c}(1) \\
\text { Lgrowth }\end{array}$ & $\begin{array}{c}(2) \\
\text { Llevel }\end{array}$ & $\begin{array}{c}(3) \\
\text { Llevel and Lgrowth }\end{array}$ & $\begin{array}{l}\text { (4) } \\
\text { Third inst }\end{array}$ & $\begin{array}{c}(5) \\
\text { Tier1 risk caprat }\end{array}$ \\
\hline PPPR & $\begin{array}{c}1.432^{* * *} \\
(0.086)\end{array}$ & $\begin{array}{c}1.425^{* * *} \\
(0.085)\end{array}$ & $\begin{array}{c}1.432^{* * *} \\
(0.088)\end{array}$ & $\begin{array}{c}1.433^{* * *} \\
(0.070)\end{array}$ & $\begin{array}{c}1.474^{* * *} \\
(0.080)\end{array}$ \\
\hline PPPLFR & $\begin{array}{c}0.307^{* * *} \\
(0.103)\end{array}$ & $\begin{array}{c}0.267^{* * *} \\
(0.082)\end{array}$ & $\begin{array}{c}0.297^{* * *} \\
(0.089)\end{array}$ & $\begin{array}{l}0.258^{* *} \\
(0.117)\end{array}$ & $\begin{array}{c}0.313^{* *} \\
(0.159)\end{array}$ \\
\hline LIQASSET & $\begin{array}{c}0.016 \\
(0.072)\end{array}$ & $\begin{array}{c}0.012 \\
(0.074)\end{array}$ & $\begin{array}{c}0.013 \\
(0.074)\end{array}$ & $\begin{array}{c}0.010 \\
(0.063)\end{array}$ & $\begin{array}{l}-0.055 \\
(0.066)\end{array}$ \\
\hline COREDEP & $\begin{array}{c}0.361^{* *} \\
(0.143)\end{array}$ & $\begin{array}{c}0.338^{* * *} \\
(0.125)\end{array}$ & $\begin{array}{l}0.358^{* *} \\
(0.140)\end{array}$ & $\begin{array}{c}0.330^{* *} \\
(0.149)\end{array}$ & $\begin{array}{c}0.247 \\
(0.155)\end{array}$ \\
\hline TCAP & $\begin{array}{c}0.848^{* * *} \\
(0.143)\end{array}$ & $\begin{array}{c}0.835^{* * *} \\
(0.130)\end{array}$ & $\begin{array}{c}0.849^{* * *} \\
(0.145)\end{array}$ & $\begin{array}{c}0.823^{* * *} \\
(0.150)\end{array}$ & \\
\hline LOANCOM & $\begin{array}{c}-1.609^{* * *} \\
(0.317)\end{array}$ & $\begin{array}{c}-1.610^{* * *} \\
(0.303)\end{array}$ & $\begin{array}{c}-1.619^{* * *} \\
(0.316)\end{array}$ & $\begin{array}{c}-1.613^{* * *} \\
(0.288)\end{array}$ & $\begin{array}{c}-1.620^{* * *} \\
(0.299)\end{array}$ \\
\hline CHGCOREDEP & $\begin{array}{c}1.188^{* * *} \\
(0.448)\end{array}$ & $\begin{array}{c}1.064^{* * *} \\
(0.369)\end{array}$ & $\begin{array}{c}1.153^{* * *} \\
(0.404)\end{array}$ & $\begin{array}{l}1.049^{* *} \\
(0.483)\end{array}$ & $\begin{array}{l}1.268^{* *} \\
(0.605)\end{array}$ \\
\hline SMALLBANK & $\begin{array}{c}0.163^{* * *} \\
(0.031)\end{array}$ & $\begin{array}{c}0.175^{* * *} \\
(0.034)\end{array}$ & $\begin{array}{c}0.181^{* * *} \\
(0.035)\end{array}$ & $\begin{array}{c}0.159^{* * *} \\
(0.030)\end{array}$ & $\begin{array}{c}0.169^{* * *} \\
(0.033)\end{array}$ \\
\hline MIDBANK & $\begin{array}{c}0.085^{* * *} \\
(0.013)\end{array}$ & $\begin{array}{c}0.098^{* * *} \\
(0.017)\end{array}$ & $\begin{array}{c}0.103^{* * *} \\
(0.017)\end{array}$ & $\begin{array}{c}0.081^{* * *} \\
(0.013)\end{array}$ & $\begin{array}{c}0.082^{* * *} \\
(0.014)\end{array}$ \\
\hline$B U S \dot{F} q 2 q 4$ & $\begin{array}{c}-0.090^{* * *} \\
(0.014)\end{array}$ & & $\begin{array}{c}-0.092^{* * *} \\
(0.015)\end{array}$ & & \\
\hline$B U S F 2019$ & & $\begin{array}{c}0.000^{* * *} \\
(0.000)\end{array}$ & $\begin{array}{c}0.000^{* * *} \\
(0.000)\end{array}$ & & \\
\hline Tier1CapRiskBased & & & & & $\begin{array}{c}0.282^{* * *} \\
(0.061)\end{array}$ \\
\hline Constant & $\begin{array}{c}-0.677^{* * *} \\
(0.184)\end{array}$ & $\begin{array}{c}-0.664^{* * *} \\
(0.169)\end{array}$ & $\begin{array}{c}-0.691^{* * *} \\
(0.185)\end{array}$ & $\begin{array}{c}-0.640 * * * \\
(0.186)\end{array}$ & $\begin{array}{c}-0.540^{* * *} \\
(0.192)\end{array}$ \\
\hline Observations & 4,069 & 4,079 & 4,069 & 4,079 & 4,079 \\
\hline R-squared & 0.282 & 0.294 & 0.285 & 0.292 & 0.256 \\
\hline
\end{tabular}

Note: Dependent variable: Growth in small business and farm lending from 2019Q4 through 2020Q2. Instrumental variables estimation. See text for variable definitions. Lgrowth refers to specifications with business and farm lending growth from 2019Q@ to 2019Q4 added, while Llevel adds business and farm lending in levels for 2019Q4. Third instrument adds a third instrumental variable, as described in text. Tier1 risk caprat adds 2019Q4 value of riskadjusted tier 1 capital ratio. Standard errors in parentheses clustered by bank size. *** $\mathrm{p}<0.01 ; * * \mathrm{p}<0.05 ; *$ $\mathrm{p}<0.1$ 
TABLE 7. Changes in estimation

\begin{tabular}{|c|c|c|c|c|}
\hline & $\begin{array}{c}(1) \\
\text { Robust SE }\end{array}$ & $\begin{array}{l}(2) \\
\text { Regular SE }\end{array}$ & $\begin{array}{c}(3) \\
\text { Weighted LS }\end{array}$ & $\begin{array}{c}(4) \\
5 \% \text { Cond. Var. Winsor }\end{array}$ \\
\hline & & & & \\
\hline PPPR & $\begin{array}{c}1.425^{* * *} \\
(0.225)\end{array}$ & $\begin{array}{c}1.425^{* * *} \\
(0.209)\end{array}$ & $\begin{array}{c}1.982^{* * *} \\
(0.703)\end{array}$ & $\begin{array}{c}1.433^{* * *} \\
(0.070)\end{array}$ \\
\hline PPPLFR & $\begin{array}{c}0.278 \\
(0.344)\end{array}$ & $\begin{array}{c}0.278 \\
(0.337)\end{array}$ & $\begin{array}{c}0.324 \\
(0.812)\end{array}$ & $\begin{array}{c}0.258^{* *} \\
(0.117)\end{array}$ \\
\hline LIQASSET & $\begin{array}{c}0.015 \\
(0.111)\end{array}$ & $\begin{array}{c}0.015 \\
(0.103)\end{array}$ & $\begin{array}{c}0.326 \\
(0.556)\end{array}$ & $\begin{array}{c}0.010 \\
(0.063)\end{array}$ \\
\hline COREDEP & $\begin{array}{c}0.341 \\
(0.247)\end{array}$ & $\begin{array}{c}0.341 \\
(0.243)\end{array}$ & $\begin{array}{l}-0.130 \\
(0.631)\end{array}$ & $\begin{array}{c}0.330^{* *} \\
(0.149)\end{array}$ \\
\hline TCAP & $\begin{array}{c}0.834^{* * *} \\
(0.306)\end{array}$ & $\begin{array}{c}0.834^{* * *} \\
(0.305)\end{array}$ & $\begin{array}{l}-0.618 \\
(1.011)\end{array}$ & $\begin{array}{c}0.823^{* * *} \\
(0.150)\end{array}$ \\
\hline LOANCOM & $\begin{array}{c}-1.602^{* * *} \\
(0.444)\end{array}$ & $\begin{array}{c}-1.602^{* * *} \\
(0.408)\end{array}$ & $\begin{array}{l}-1.458^{*} \\
(0.785)\end{array}$ & $\begin{array}{c}-1.613^{* * *} \\
(0.288)\end{array}$ \\
\hline CHGCOREDEP & $\begin{array}{c}1.098 \\
(0.944)\end{array}$ & $\begin{array}{c}1.098 \\
(0.932)\end{array}$ & $\begin{array}{c}1.321 \\
(1.923)\end{array}$ & $\begin{array}{c}1.049^{* *} \\
(0.483)\end{array}$ \\
\hline SMALLBANK & $\begin{array}{c}0.158^{* * *} \\
(0.060)\end{array}$ & $\begin{array}{c}0.158^{* * *} \\
(0.052)\end{array}$ & $\begin{array}{c}0.223 \\
(0.145)\end{array}$ & $\begin{array}{c}0.159^{* * *} \\
(0.030)\end{array}$ \\
\hline MIDBANK & $\begin{array}{c}0.081^{* *} \\
(0.039)\end{array}$ & $\begin{array}{c}0.081^{* * *} \\
(0.030)\end{array}$ & $\begin{array}{c}0.058^{* *} \\
(0.028)\end{array}$ & $\begin{array}{c}0.081^{* * *} \\
(0.013)\end{array}$ \\
\hline Constant & $\begin{array}{c}-0.651^{* *} \\
(0.281)\end{array}$ & $\begin{array}{c}-0.651^{* *} \\
(0.276)\end{array}$ & $\begin{array}{l}-0.355 \\
(0.562)\end{array}$ & $\begin{array}{c}-0.640^{* * *} \\
(0.186)\end{array}$ \\
\hline Observations & 4,079 & 4,079 & 4,079 & 4,079 \\
\hline $\mathrm{R}$-squared & 0.291 & 0.291 & 0.134 & 0.292 \\
\hline
\end{tabular}

Note: Dependent variable: Growth in small business or farm lending from 2019Q4 through 2020Q2, as indicated. Instrumental variables estimation. See text for variable definitions and changes in estimation methods across columns. Standard errors in parentheses clustered by bank size. ${ }^{* * *} \mathrm{p}<0.01 ;{ }^{* *} \mathrm{p}<0.05$; $* \mathrm{p}<0.1$ 
TABLE 8. Capital ratio growth

\begin{tabular}{|c|c|c|c|c|c|c|}
\hline & $\begin{array}{c}(1) \\
\text { Tier1ra }\end{array}$ & $\begin{array}{c}(2) \\
\text { Tier1ra } \\
\end{array}$ & $\begin{array}{c}(3) \\
\text { Tier1ra } \\
\end{array}$ & $\begin{array}{c}(4) \\
\text { Total capital }\end{array}$ & $\begin{array}{c}(5) \\
\text { Total capital }\end{array}$ & $\begin{array}{c}\text { (6) } \\
\text { Total capital }\end{array}$ \\
\hline PPPR & $\begin{array}{c}0.579^{* * *} \\
(0.151)\end{array}$ & $\begin{array}{c}0.702^{* * *} \\
(0.029)\end{array}$ & & $\begin{array}{c}-0.337^{* * *} \\
(0.010)\end{array}$ & $\begin{array}{c}-0.337^{* * *} \\
(0.029)\end{array}$ & \\
\hline PPPLFR & $\begin{array}{c}1.085^{* * *} \\
(0.311)\end{array}$ & & $\begin{array}{c}1.463^{* * *} \\
(0.073)\end{array}$ & $\begin{array}{c}-0.262^{* *} \\
(0.123)\end{array}$ & & $\begin{array}{c}-0.481^{* * *} \\
(0.073)\end{array}$ \\
\hline LIQASSET & $\begin{array}{c}0.227^{* * * *} \\
(0.016)\end{array}$ & $\begin{array}{c}0.162^{* * *} \\
(0.028)\end{array}$ & $\begin{array}{c}0.432^{* * *} \\
(0.080)\end{array}$ & $\begin{array}{c}0.056^{* * * *} \\
(0.021)\end{array}$ & $\begin{array}{c}0.014 \\
(0.014)\end{array}$ & $\begin{array}{c}-0.066^{* * *} \\
(0.007)\end{array}$ \\
\hline COREDEP & $\begin{array}{c}0.804^{* * *} \\
(0.245)\end{array}$ & $\begin{array}{c}-0.082^{* * *} \\
(0.028)\end{array}$ & $\begin{array}{c}0.860^{* * *} \\
(0.177)\end{array}$ & $\begin{array}{c}-0.308^{* * *} \\
(0.105)\end{array}$ & $\begin{array}{l}-0.020^{*} \\
(0.012)\end{array}$ & $\begin{array}{c}-0.339 * * * \\
(0.097)\end{array}$ \\
\hline TCAP & $\begin{array}{c}-0.887^{* * *} \\
(0.206)\end{array}$ & $\begin{array}{c}-1.457^{* * *} \\
(0.052)\end{array}$ & $\begin{array}{c}-0.966^{* * *} \\
(0.218)\end{array}$ & $\begin{array}{c}-0.828^{* * *} \\
(0.143)\end{array}$ & $\begin{array}{c}-0.511^{* * *} \\
(0.058)\end{array}$ & $\begin{array}{c}-0.776 * * * \\
(0.126)\end{array}$ \\
\hline LOANCOM & $\begin{array}{l}-0.336 \\
(0.235)\end{array}$ & $\begin{array}{c}-0.075^{* * *} \\
(0.013)\end{array}$ & $\begin{array}{c}0.724^{* * *} \\
(0.064)\end{array}$ & $\begin{array}{c}0.238^{* * *} \\
(0.039)\end{array}$ & $\begin{array}{c}0.009 \\
(0.009)\end{array}$ & $\begin{array}{c}-0.379^{* * *} \\
(0.060)\end{array}$ \\
\hline CHGCOREDEP & $\begin{array}{c}3.626^{* * *} \\
(0.921)\end{array}$ & $\begin{array}{c}0.586^{* * *} \\
(0.052)\end{array}$ & $\begin{array}{c}4.002^{* * *} \\
(0.469)\end{array}$ & $\begin{array}{l}-0.523 \\
(0.388)\end{array}$ & $\begin{array}{c}0.217^{* * *} \\
(0.035)\end{array}$ & $\begin{array}{c}-0.746^{* * *} \\
(0.221)\end{array}$ \\
\hline SMALLBANK & $\begin{array}{c}-0.144^{* * *} \\
(0.009)\end{array}$ & $\begin{array}{c}-0.194^{* * *} \\
(0.010)\end{array}$ & $\begin{array}{c}-0.259^{* * *} \\
(0.012)\end{array}$ & $\begin{array}{c}-0.066^{* * *} \\
(0.009)\end{array}$ & $\begin{array}{c}-0.050^{* * *} \\
(0.009)\end{array}$ & $\begin{array}{c}0.001 \\
(0.002)\end{array}$ \\
\hline MIDBANK & $\begin{array}{c}-0.090^{* * *} \\
(0.003)\end{array}$ & $\begin{array}{c}-0.137^{* * *} \\
(0.002)\end{array}$ & $\begin{array}{c}-0.117^{* * *} \\
(0.006)\end{array}$ & $\begin{array}{c}-0.018^{* * *} \\
(0.005)\end{array}$ & $\begin{array}{l}-0.002 \\
(0.003)\end{array}$ & $\begin{array}{c}-0.002^{* *} \\
(0.001)\end{array}$ \\
\hline Constant & $\begin{array}{c}-1.064^{* * *} \\
(0.207)\end{array}$ & $\begin{array}{c}-0.142^{* * *} \\
(0.042)\end{array}$ & $\begin{array}{c}-0.903^{* * *} \\
(0.163)\end{array}$ & $\begin{array}{c}0.464^{* * *} \\
(0.123)\end{array}$ & $\begin{array}{c}0.153^{* * *} \\
(0.014)\end{array}$ & $\begin{array}{c}0.368^{* * *} \\
(0.101)\end{array}$ \\
\hline $\begin{array}{l}\text { Observations } \\
\text { R-squared }\end{array}$ & 4,086 & $\begin{array}{l}4,749 \\
0.022\end{array}$ & 4,096 & 4,086 & $\begin{array}{l}4,749 \\
0.021\end{array}$ & 4,096 \\
\hline
\end{tabular}

Note: Dependent variable: Growth in tier 1 risk-adjusted (tier1ra) or total capital ratio from 2019Q4 through 2020Q2, as indicated. Instrumental variables estimation. See text for variable definitions. Standard errors in parentheses clustered by bank size. ${ }^{* * *} \mathrm{p}<0.01 ; * * \mathrm{p}<0.05 ;{ }^{*} \mathrm{p}<0.1$ 


\section{APPENDIX}

TABLE A1. TOBIT and First stage estimation

\begin{tabular}{|c|c|c|c|c|c|c|}
\hline & $\begin{array}{c}(1) \\
\text { TOB PPPR }\end{array}$ & $\begin{array}{c}(2) \\
\text { TOB PPPLF }\end{array}$ & $\begin{array}{c}(3) \\
\text { TOB PPP }\end{array}$ & $\begin{array}{c}(4) \\
\text { TOB PPPLF }\end{array}$ & $\begin{array}{c}(5) \\
\text { PPP 1st stg }\end{array}$ & $\begin{array}{c}(6) \\
\text { PPPLF 1st stg }\end{array}$ \\
\hline Indmix & $\begin{array}{c}2.459^{* * *} \\
(0.488)\end{array}$ & $\begin{array}{c}4.331^{* * *} \\
(0.468)\end{array}$ & $\begin{array}{l}1.198^{* *} \\
(0.490)\end{array}$ & $\begin{array}{c}3.411^{* * *} \\
(1.004)\end{array}$ & $\begin{array}{c}1.248^{* *} \\
(0.492)\end{array}$ & $\begin{array}{c}4.271^{* * *} \\
(0.877)\end{array}$ \\
\hline SBA2019 & $\begin{array}{l}0.203^{* *} \\
(0.087)\end{array}$ & $\begin{array}{c}1.054^{* * *} \\
(0.064)\end{array}$ & $\begin{array}{c}0.405^{* * *} \\
(0.075)\end{array}$ & $\begin{array}{c}1.207^{* * *} \\
(0.178)\end{array}$ & $\begin{array}{c}0.215^{* *} \\
(0.090)\end{array}$ & $\begin{array}{c}-0.449^{* * *} \\
(0.159)\end{array}$ \\
\hline LIQASSET & & & & & $\begin{array}{l}-0.055 \\
(0.058)\end{array}$ & $\begin{array}{c}-1.480^{* * *} \\
(0.060)\end{array}$ \\
\hline COREDEP & & & & & $\begin{array}{l}-0.190 \\
(0.122)\end{array}$ & $\begin{array}{c}-3.132^{* * *} \\
(0.299)\end{array}$ \\
\hline TCAP & & & & & $\begin{array}{c}-1.215^{* * *} \\
(0.116)\end{array}$ & $\begin{array}{c}-5.866^{* * *} \\
(1.240)\end{array}$ \\
\hline LOANCOM & & & & & $\begin{array}{c}0.115^{* *} \\
(0.051)\end{array}$ & $\begin{array}{c}2.744^{* * *} \\
(0.717)\end{array}$ \\
\hline CHGCOREDEP & & & & & $\begin{array}{c}-1.253^{* * *} \\
(0.138)\end{array}$ & $\begin{array}{c}-8.349 * * * \\
(0.069)\end{array}$ \\
\hline SMALLBANK & & & $\begin{array}{c}-0.299^{* * *} \\
(0.007)\end{array}$ & $\begin{array}{c}-0.283^{* * *} \\
(0.008)\end{array}$ & $\begin{array}{c}-0.321^{* * *} \\
(0.005)\end{array}$ & $\begin{array}{c}-0.162^{* * *} \\
(0.046)\end{array}$ \\
\hline MIDBANK & & & $\begin{array}{c}-0.051^{* * *} \\
(0.003)\end{array}$ & $\begin{array}{c}-0.036^{* * *} \\
(0.005)\end{array}$ & $\begin{array}{c}-0.080^{* * *} \\
(0.002)\end{array}$ & $\begin{array}{c}-0.060^{* * *} \\
(0.020)\end{array}$ \\
\hline Constant & $\begin{array}{c}0.241^{* * *} \\
(0.049)\end{array}$ & $\begin{array}{c}-1.031^{* * *} \\
(0.117)\end{array}$ & $\begin{array}{c}0.506^{* * *} \\
(0.009)\end{array}$ & $\begin{array}{c}-0.789^{* * *} \\
(0.062)\end{array}$ & $\begin{array}{c}0.834^{* * *} \\
(0.106)\end{array}$ & $\begin{array}{c}2.614^{* * *} \\
(0.355)\end{array}$ \\
\hline Observations & 4,741 & 4,086 & 4,741 & 4,086 & 4,741 & 4,086 \\
\hline
\end{tabular}

Note: Dependent variable: PPP or PPPLF ratios, as indicated. TOBIT (Models (1) through (4)) and 2SLS first stage regressions (Models (5) and (6)) for PPP and PPPLF ratios as indicated. Standard errors in parentheses clustered by bank size. $* * * \mathrm{p}<0.01$; ** $\mathrm{p}<0.05 ;{ }^{*} \mathrm{p}<0.1$ 
TABLE A2. Alternative outlier treatments

\begin{tabular}{|c|c|c|c|c|}
\hline & (1) & (2) & $(3)$ & (4) \\
\hline & No winsor & $\mathrm{PPP}(\mathrm{LF})$ winsor & $1 \%$ winsor & Truncate \\
\hline \multirow[t]{2}{*}{ PPPR } & 8.344 & 1.548 & $2.100^{* * *}$ & $7.473^{*}$ \\
\hline & $(35.861)$ & $(6.011)$ & $(0.260)$ & $(4.158)$ \\
\hline \multirow[t]{2}{*}{ PPPLFR } & -8.165 & $-13.111^{* * *}$ & -0.593 & 4.775 \\
\hline & $(20.994)$ & $(3.741)$ & $(0.505)$ & $(3.367)$ \\
\hline \multirow[t]{2}{*}{ LIQASSET } & -3.300 & -0.660 & -0.154 & -2.217 \\
\hline & $(12.714)$ & $(2.150)$ & $(0.180)$ & $(1.505)$ \\
\hline \multirow[t]{2}{*}{ COREDEP } & -8.272 & $-11.513^{*}$ & -0.212 & 3.866 \\
\hline & $(20.259)$ & $(6.688)$ & $(0.386)$ & $(2.408)$ \\
\hline \multirow[t]{2}{*}{ TCAP } & 10.548 & 0.062 & $1.056^{*}$ & $11.002^{* * *}$ \\
\hline & $(41.786)$ & $(4.792)$ & $(0.604)$ & $(3.253)$ \\
\hline \multirow[t]{2}{*}{ LOANCOM } & -29.836 & $-8.220 * * *$ & $-3.444^{* * *}$ & $-21.010^{* *}$ \\
\hline & $(91.517)$ & $(3.030)$ & $(0.996)$ & $(8.229)$ \\
\hline \multirow[t]{2}{*}{ CHGCOREDEP } & -17.728 & $-55.342^{*}$ & -1.999 & $37.092^{* * *}$ \\
\hline & $(189.447)$ & $(28.745)$ & $(1.793)$ & $(7.328)$ \\
\hline \multirow[t]{2}{*}{ SMALLBANK } & 1.438 & -1.807 & $0.313^{* * *}$ & $3.092^{*}$ \\
\hline & $(16.799)$ & $(2.526)$ & $(0.094)$ & $(1.686)$ \\
\hline \multirow[t]{2}{*}{ MIDBANK } & 1.993 & 0.372 & $0.143^{* * *}$ & $1.541^{*}$ \\
\hline & $(8.059)$ & $(0.954)$ & $(0.039)$ & $(0.839)$ \\
\hline \multirow[t]{2}{*}{ Constant } & 3.614 & 12.451 & -0.413 & $-9.248^{* * *}$ \\
\hline & $(47.535)$ & $(9.072)$ & $(0.551)$ & $(2.090)$ \\
\hline Observations & 4,079 & 4,079 & 4,079 & 4,079 \\
\hline R-squared & & & 0.080 & \\
\hline
\end{tabular}




\section{References}

Barraza, S., M. A. Rossi, and T. J. Yeager (2020, August). The short-term effect of the paycheck protection program on unemployment. mimeo.

Bartik, A. W., Z. B. Cullen, E. L. Glaeser, M. Luca, C. T. Stanton, , and A. Sunderam (2020, July). The targeting and impact of paycheck protection program loans to small businesses. NBER Working Paper 27623.

Beauregard, R., J. A. Lopez, and M. M. Spiegel (2020). Small business lending during covid-19. FRBSF Economic Letter (2020-35).

Berger, A. N., C. Bouwman, L. Norden, R. Roman, G. Udell, and T. Wang (2021, January). Is a friend in need a friend indeed? how relationship borrowers fare during the covid-19 crisis. mimeo.

BKD (2020, December). Bkd thoughtware alert: Stimulus aid for farmers \& ranchers-second chance for ppp loans \& eidl grants.

Bowman, M. (2020, September). Community banks rise to the challenge. Speech at the Community Banking in the 21st Century Research Conference, FRB St. Louis.

Cornett, M. M., J. McNutt, P. E. Strahan, and H. Tehranian (2011). Liquidity risk management and credit supply in the financial crisis. Journal of Financial Economics 101(2), 297-312.

Erel, I. and J. Liebersohn (2020, August). Does fintech substitute for banks? evidence from the paycheck protection program. NBER Working Paper No. 27659.

Granja, J., C. Makridis, C. Yannelis, and E. Zwick (2020, May). Did the paycheck protection program hit the target? Becker Friedman Institute Working Paper No. 2020-52.

Greenwald, D. L., J. Krainer, and P. Paul (2020, November). The credit line channel. FRBSF Working Paper No. 2020-26.

Hubbard, G. and M. R. Strain (2020, September). Has the paycheck protection program succeeded. Brookings Papers on Economic Activity: BPEA Conference Drafts.

James, C., J. Lu, and Y. Sun (2021, February). Time is money: Real effects of relationship lending: Evidence from community bank lending in the paycheck protection program. mimeo.

Li, L. and P. Strahan (2020). Who supplies ppp loans (and does it matter): Banks, relationships, and the covid crisis. NBER Working Paper 28286.

Liu, H. and D. Volker (2020, May). Where have the paycheck protection loans gone so far? Liberty Street Economics. 
https://libertystreeteconomics.newyorkfed.org/2020/05/where-have-the-paycheckprotection-loans-gone-so-far.html.

Rice, T. and J. Rose (2016). When good investments go bad: The contraction in community bank lending after the 2008 gse takeover. Journal of Financial Intermediation 27, 68-88.

S.B.A. (2019). Frequently asked questions. U.S. Small Business Administration, Office of Advocacy. 